\title{
NÃO PENSE, VEJA: O ESPETÁCULO DA LINGUAGEM NO PALCO DO FOME ZERO
}

\author{
Elisa Guimarães
}

FERREIRA, Dina Maria Martins. Não pense, veja: o espetáculo da linguagem no palco do Fome Zero. São Paulo: Annablume/Fapesp, 2006.

Num ensaio lúcido, crítico e abrangente, Dina Maria Martins Ferreira contextualiza, histórica e teoricamente, o "Fome Zero" - o mais visado projeto social do "Governo Lula". Ou, no dizer da autora, o "mote" desse governo.

Partilha, assim, com o leitor observações e reflexões de quem esteve mergulhada na análise da questão. Nessa análise, serve-lhe de âncora o discurso midiático cuja linguagem espetaculariza o programa "Fome Zero". E Dina - lingüista - vai sondando o espetáculo à luz dos muitos escritos que o descrevem, enquanto devassa o espaço de onde emerge Lula o sujeito que ela batiza de "sujeito indivíduo, sujeito social, sujeito político-cultural de uma nação". (p.26)

Variadíssimos textos da mídia - verbais e não-verbais - passam pelo crivo de aguda reflexão - a combinatória dos detalhes harmonizando-se com a visão do conjunto.

Nessa visão, surpreende-se o vigor de um senso crítico que tem sob a alça de mira a necessidade de que, pelo viés da linguagem, o leitor possa participar do espetáculo político "Fome Zero". Trata-se, por certo, de um intento perfeitamente consonante com a afirmação da autora quando diz que "quem constrói os objetos são os discursos e não a realidade" (p.133). O que está, pois, em jogo é o jogo da linguagem - instrumental que se redimensiona para fecundas incursões no vasto território dos sentidos.

Assim, parece interessar à autora, através da matéria-prima que andou garimpando, o desvendamento da várias feições construtoras de uma imagem embaçada e fugaz, projetora da diversidade da constituição identitária do "Governo Lula", via "Programa Fome Zero".

Os textos reveladores dessa diversidade são manifestações de um vendaval de referências - jogo instável de equilíbrios e desequilíbrios, de conjunções e dissonâncias -

\footnotetext{
* Professora Doutora da Área de Filologia e Língua Portuguesa. Depto de Letras Clássicas e Vernáculas/ FFLCH/USP; Professora Doutora do Instituto Presbiteriano Mackenzie - SP.
} 
marcas inconfundíveis do fragmentário. $\mathrm{Na}$ forma fragmentária, o finito e o infinito parecem identificar-se melhor do que na forma acabada e contida em limites.

Na sábia lida com esse material, Dina Maria Martins Ferreira leva todo um conjunto de ponderações às raias de uma reflexão crítica - esta entendida como um exercício que se abre para possíveis desdobramentos. Prefere, pois, não correr o risco de uma cristalização definitiva e acadêmica, ou não se carregar de responsabilidade de conclusões irreversíveis. Propõe, antes, uma série de sugestões a serem apreendidas pelo leitor perspicaz, capaz de ler nas entrelinhas. Sob a força desse propósito é que define seu livro como "um construtor e não um produto acabado e terminado" (p.12). Aí, observações críticas associam-se a segmentos de fina ironia - sobre um alicerce de rara independência de pensamento: "Como poderemos vender ao Mundo o "Fome Zero" com um presidente rotundo?" (p.137). E continua: (...) estamos em plena peça teatral na qual o principal ator é o marketing do "Fome Zero"(p.139).

Desce, assim, a autora ao terreno prático das possibilidades, transmite uma série de valores e ensina a refletir. Nesse ensinamento, encara Lula e o poder apresentando o projeto - apresentação que "rehistoriciza a glória da História brasileira pela história da fome" (p.13).

Sabemos que a História, entretanto, não é como um trem que segue o seu percurso dentro dos trilhos de dadas intenções, e nem obedece às horas marcadas de muitas esperanças. Antes, reformula-se, reorganiza-se, reestrutura-se sob a mira da crítica, da mundividência do historiador. Emoldurando a História existe o contexto, existe o tônus subjetivo, existe a constelação dos sentidos - o que nos leva além da superfície, no encalço das profundezas.

É bem esta a rota apontada pela substancialidade do texto de Dina Maria Martins Ferreira, enquanto analista dos textos selecionados da mídia. Em ponderada fusão entre discurso, mídia e produção de identidades, a autora identifica o discurso político como um ato de fala pragmático, interativo, movido pelo afã do poder. Um discurso que ostenta, portanto, ao máximo, a força da linguagem e as circunstâncias que se dão no ato de fala, tanto as lingüísticas - quanto as paralingüísticas e as extralinguiísticas - todas elas comprometidas com o espetáculo da linguagem edificando-se pelo espetáculo político.

Escrito com ponderação e meticulosidade, o texto abriga um convite: "a luta precisa continuar para que a espetacularização prossiga". Par a par com o convite, um apelo inscrito no instigante título da obra - Não pense, VEJA.

É momento de lembrar que assim também pondera Camões no Canto $\mathrm{X}$ de $O s$ Lusíadas: "Não se aprende, Senhor, na fantasia/ sonhando, imaginando ou estudando/, Senão VENDO, tratando, e pelejando". 